OPEN ACCESS

Edited by:

Hao Wang,

Tianjin Medical University General Hospital, China

Reviewed by:

Maarten Naesens,

KU Leuven, Belgium

Longshan Liu,

Sun Yat-Sen University,

China

Dengping Yin,

University of Chicago,

United States

*Correspondence:

Zheng Jenny Zhang

zjzhang@northwestern.edu

Specialty section:

This article was submitted to Alloimmunity and Transplantation,

a section of the journal

Frontiers in Immunology

Received: 31 January 2021

Accepted: 27 April 2021

Published: 20 May 2021

Citation:

Lai X, Zheng X, Mathew JM, Gallon L, Leventhal JR and Zhang ZJ (2021) Tackling Chronic Kidney Transplant Rejection: Challenges and Promises.

Front. Immunol. 12:661643. doi: 10.3389/fimmu.2021.661643

\section{Tackling Chronic Kidney Transplant Rejection: Challenges and Promises}

\author{
Xingqiang Lai ${ }^{1,2,3}$, Xin Zheng ${ }^{4}$, James M. Mathew ${ }^{1,2}$, Lorenzo Gallon ${ }^{1,5}$, \\ Joseph R. Leventhal ${ }^{1,2}$ and Zheng Jenny Zhang ${ }^{1,2 *}$ \\ ${ }^{1}$ Comprehensive Transplant Center, Northwestern University Feinberg School of Medicine, Chicago, IL, United States, \\ 2 Department of Surgery, Northwestern University Feinberg School of Medicine, Chicago, IL, United States, ${ }^{3}$ Organ \\ Transplant Center, the Second Affiliated Hospital of Guangzhou Medical University, Guangzhou, China, ${ }^{4}$ Department of \\ Urology, Beijing Youan Hospital, Capital Medical University, Beijing, China, ${ }^{5}$ Department of Medicine, Nephrology, \\ Northwestern University Feinberg School of Medicine, Chicago, IL, United States
}

Despite advances in post-transplant management, the long-term survival rate of kidney grafts and patients has not improved as approximately forty percent of transplants fails within ten years after transplantation. Both immunologic and non-immunologic factors contribute to late allograft loss. Chronic kidney transplant rejection (CKTR) is often clinically silent yet progressive allogeneic immune process that leads to cumulative graft injury, deterioration of graft function. Chronic active T cell mediated rejection (TCMR) and chronic active antibody-mediated rejection (ABMR) are classified as two principal subtypes of CKTR. While significant improvements have been made towards a better understanding of cellular and molecular mechanisms and diagnostic classifications of CKTR, lack of early detection, differential diagnosis and effective therapies continue to pose major challenges for long-term management. Recent development of high throughput cellular and molecular biotechnologies has allowed rapid development of new biomarkers associated with chronic renal injury, which not only provide insight into pathogenesis of chronic rejection but also allow for early detection. In parallel, several novel therapeutic strategies have emerged which may hold great promise for improvement of long-term graft and patient survival. With a brief overview of current understanding of pathogenesis, standard diagnosis and challenges in the context of CKTR, this mini-review aims to provide updates and insights into the latest development of promising novel biomarkers for diagnosis and novel therapeutic interventions to prevent and treat CKTR.

Keywords: chronic allograft rejection, kidney transplant, biomarkers, IFTA, T cells mediated rejection

\section{INTRODUCTION}

Chronic kidney transplant rejection (CKTR) is characterized by progressive decrease of renal graft function that starts to manifest at one-year after the transplantation and usually accompanied by hypertension and proteinuria (1). CKTR usually occurs in patients with insufficient immunosuppression or medication nonadherence (2). While Persistent allogeneic immune response remains a major cause $(3,4)$, multiple risk factors, e.g. early ischemia reperfusion injury, acute rejection episodes and transplant infectious diseases, can contribute to the development and 
progression of CKTR. Histologically, there are two principal distinct subtypes of CKTR, namely chronic active antibodymediated rejection (ABMR) and chronic active $\mathrm{T}$ cell-mediated rejection (TCMR) according to the revised Banff criteria $(5,6)$. It is not uncommon that both chronic active TCMR/ABMR co-exist and lead to rapid loss of graft function (7-9).

Effective treatment and prognosis of CKTR are largely dependent upon the severity and reversibility of rejection at the time of diagnosis. However, it remains a major challenge to identify early changes before irreversible damage to the graft occurs. Currently, no immunotherapies are clinically proven to be effective in prevention and treatment of CKTR, particularly ABMR. Recent advances in high-throughput cellular and molecular biotechnologies have allowed for in-depth analyses of cellular and molecular processes and deconvolutions of mechanisms underlying CKTR and have led to identification and validation of new molecular and cellular biomarkers through non-invasive or minimal-invasive approaches. The discovery of these biomarkers holds tremendous promise for early detection and development of promising novel therapies for improvement of kidney transplant outcomes. This review will first provide a brief summary on current understanding of pathogenesis and standard mothed challenges for the diagnosis of CKTR, and then, focus on more in-depth discussions to the area of biomarker discovery and novel therapeutic interventions to improve long term transplant outcome.

\section{PATHOGENESIS OF CHRONIC ACTIVE ABMR AND CHRONIC TCMR}

Chronic active ABMR represents most cases of CKTR (2), featuring transplant glomerulopathy along with severe peritubular capillary basement membrane multilayering and new onset arterial intimal fibrosis. In contract, chronic active TCMR is determined based on inflammation in areas of the cortex with interstitial fibrosis and tubular atrophy (i-IFTA), a hallmark feature of CKTR in addition to tubulitis. The newly revised Banff criteria of chronic active TCMR recognize the pathogenic importance of TCMR in the development of chronic interstitial inflammation leading to i-IFTA, nonetheless, it does not discriminate alloimmune-mediated tissue injury from 'non-specific injuries, particularly calcineuirn inhibitor (CNI) mediated nephrotoxicities $(10,11)$.

While precise mechanisms underlying ABMR remain elusive, it is believed that the interaction of donor-specific alloantibodies (DSAs) against donor HLA antigens, especially HLA class II antigens expressed by endothelial cells of the microvascular circulation, initiates ABMR (12). DSAs binding to endothelial cells leads to a cascade of molecular events, including complement activation that may contribute to endothelial dysfunction, microvascular inflammation and remodeling, and ultimately results in irreversible tissue injury (13). B cell deficiency resulted in reduced transplant glomerulopathy, decreased microvascular inflammation, reduced macrophage infiltration and IFN $\gamma$ transcripts in the allograft (14), which underscores the importance of $B$ cells in the pathogenesis of ABMR. In addition to uncontrolled allogeneic immune response due to insufficient immunosuppression or nonadherence, early inflammatory events such as acute TCMR and viral infection are suggested to be risk factors for DSA (dnDSA) production (15-17). Preceding TCMR is found to be strongly correlated with development of chronic active ABMR dnDSA (7). Moreover, it has been shown in biopsyproven chronic active ABMR cases that T cells (especially CD8+ T cells) and macrophages are the dominant infiltrating cell types in glomerulus, whereas B cells are frequently observed in the tubulointerstitial compartment, indicating that both $\mathrm{T}$ cells and macrophages play a pivotal role in renal chronic ABMR (18). The involvement of NK cells in ABMR has recently gained attention. Recent studies have revealed that NK cells are involved in ABMR via CD16a Fc receptors $(19,20)$. Depletion of NK cells significantly mitigates DSA-induced chronic allograft vasculopathy (CAV) (21). NK cells increase IFN $\gamma$ production after exposure to alloantigens through an antibody-dependent cellular cytotoxicity-like mechanisms, which is associated with an increased risk for ABMR (22) and NK cell infiltration predicts poor outcome after kidney transplantation (23).

Persistent $\mathrm{T}$ cell-mediated injuries can lead to chronic active TCMR (24). Alloreactive effector memory T Cells (Tem), particularly CD8+ Tem subsets (express increased CD44hi, CD45RO+, OX40, KLRG-1 and BLIMP-1), are implicated in the development of TCMR (25). Unlike naïve T cells, Tem cells are known for their low activation threshold, robust effector functions, and resistance to conventional immunosuppression and costimulation blockade (26). Memory T cells are originated from environmental antigens or generated from previous rejection episodes and once activated, they enter into the renal interstitium and secrete several cytokines such as IFN $\gamma$ and TGF $\beta$, and subsequently trigger a cascade of inflammation leading to tubulitis (27). Chronic TCMR also results in renal vasculature injuries, such as arterial inflammation and intimal fibrosis (6). In a recent study, Claudia and colleagues (25) demonstrated that CD8+ effector memory $\mathrm{T}$ cells mediated by the OX40 gene pathway play an important role in the pathogenesis of chronic TCMR.

\section{CURRENT DIAGNOSIS AND CHALLENGES}

Early diagnosis of CKTR determines successful therapeutic interventions and prognosis. CKTR is a slowly progressive process in which pathologic changes as such vascular inflammation and i-IFTA do not have clinical manifestations until late stages. In addition, differential diagnosis is extremely important to distinguish CKTR from late graft dysfunction caused by other complications including CNI toxicity, BKvirus associated nephropathy and recurrent renal diseases, each of which requires different treatment. Transplant patients are subjected to routine laboratory tests for continuous graft monitoring. Serum creatinine $(\mathrm{sCr})$, blood urea nitrogen (BUN) and cystatin C are commonly used to evaluate graft function. The estimated glomerular filtration rate (eGFR), 
calculated based on sCr level, age, weight and gender, is considered as an accurate indicator and predictor for graft function and long-term graft survival (28). Proteinuria $>500$ $\mathrm{mg} /$ day is also considered as a marker of chronic kidney allograft dysfunction (29). However, because chronic rejection is an indolent process with slow progression in pathologic changes (30), these aforementioned tests are non-specific, often failing to detect renal damage at early stages and easily influenced by other non-immune injuries can also influence the results. Emergence of circulating de novo DSAs is associated with increased risk for graft failure as a result of chronic active ABMR (31, 32). Prospective monitoring for DSAs may be indicative for early treatment before irreversible graft injury $(33,34)$, however, not all DSAs are doomed to be pathogenic (35) and DSA levels may not correlate with tissue injury (15). Imaging technologies such as Doppler ultrasonography (US), Contrast-enhanced ultrasound (CEUS) and Magnetic Resonance Imaging (MRI) are non-invasive complementary methodologies used to assist in the early diagnosis of both acute and chronic graft rejection by evaluating renal vasculature resistance (US) (36, 37), graft blood perfusion (CEUS) (38), and anatomical changes (MRI) such as fibrosis (39). However, findings from these tests are mostly non-specific with limited value in guiding the clinical treatment.

Currently, graft biopsies still remain the gold standard for diagnosing graft rejection. Graft histology provides visual evidence of the underlying pathology and pathogenesis of graft dysfunction. More recently, genetic analysis of biopsy tissue has been used to assist in the differential diagnosis of allograft rejection in conjunction with histology and immunohistochemistry. The Banff classification, founded in 1991, has established specific criteria for the diagnosis of kidney allograft rejection. It has been updated multiple times in the past two decades (5). C4d complement fragment deposition in the peritubular capillaries was regarded as a marker for ABMR (40), but removed as a diagnostic criterion in the latest Banff (2019) Classification Criteria for chronic active ABMR due to the emergence of C4d negative ABMR (41). Although histological examination through renal biopsy remains the diagnostic gold standard criterion, it cannot be carried out too often due to its invasiveness. Graft needle biopsy can cause various surgery-related complications, such as perinephric hematoma, arteriovenous fistula, bleeding, infection. In addition, there are other limitations associated with histologic examination, e.g. lack of standardization and quantitation, sampling errors and accurate diagnosis largely relies on the pathologists' skills (42). Therefore, non-/minimallyinvasive and predictive biomarkers are highly desirable for early diagnosis and tailored inventions to delay or prevent CKTR and improve graft longevity.

\section{POTENTIAL BIOMARKERS FOR EARLY DIAGNOSIS AND PROGNOSIS}

Recent development of high-throughput cellular and molecular biotechnologies has led to tremendous advances in biomarker discoveries in the field of transplantation, with great promise for better understanding and management of CKTR. Contributions of biomarker studies are multifold, including 1) generating new insight into molecular mechanisms of CKTR, 2) allowing for early and differential diagnosis, 3) providing evaluation of therapeutic intervention, and 4) predicting prognosis. Principal characteristics of the biomarkers have been thoroughly reviewed elsewhere (42-44). Although most studies have centered in exploring non-invasive biomarkers for ischemia/reperfusion injury and acute allograft rejection in blood and urine (42), a variety of biomarkers generated from studies in renal protocol biopsies and blood and urine samples are suggestive for diagnosis and prognosticator for CKTR. Based on the characteristics of the biomarkers and technologies used, biomarkers pertaining to CKTR can be divided into five main categories: transcriptomic biomarkers, Epigenetic biomarkers, Proteomic biomarkers, and Metabolomic biomarkers, and cellular biomarkers, which are summarized Table 1, and also briefly discussed in the following sections.

\section{Transcriptomic Biomarkers}

These biomarkers are generated by high-throughput gene or transcriptome profiling, also termed transcriptomics, using microarray and next generation gene sequencing technologies. These studies have been more commonly performed on renal biopsy samples as they provide sufficient material for RNA extraction. As listed in Table 1, gene signatures associated with fibrosis, i-IFTA, chronic rejection (ABMR and TCMR) and graft failure can be identified by determining gene expression profiling (45-53). Importantly, the gene set has higher predictive capacity than that of baseline clinical variables, and clinical and pathological variables. One notion from these studies is that similar gene signatures for acute rejection are also indicative of CKTR. For example, a study by Khatri et al. (85) revealed 11 genes associated with acute rejection across different engrafted tissues, among which 7 genes (CD6, INPP5D, ISG20, NKG7, $P S M B$ 9, RUNX3, and TAP1) were identified as predictors for the development of progressive i-IFTA at 24 months posttransplant (45). More interestingly, a set of four gene markers (vimentin, NKCC2, E-cadherin, and $18 S$ rRNA) in urine samples has been identified as reliable non-invasive biomarkers for i-IFTA (46).

\section{Epigenetic Biomarkers}

Epigenetic modifications and regulators control relevant gene expression and function in response to altered biological process, and thereby can be employed as disease biomarkers (86). Epigenetic modifications include cytosine methylation of DNA at cytosine-phosphate diester-guanine dinucleotides, microRNA interactions, histone modifications, and chromatin remodeling complexes (87), which occur to genome without alteration of the DNA sequence. Epigenetics is an emerging field of research in kidney transplantation. Most studies have been performed in the context of ischemia and reperfusion injury and acute rejection, demonstrating the implication of aberrant DNA methylation (88). Recent studies in both humans and animals (54, 89) have shown that altered epigenetic modifications, particularly DNA methylation, influences the activation, proliferation, 
TABLE 1 | Potential biomarkers for chronic rejection.

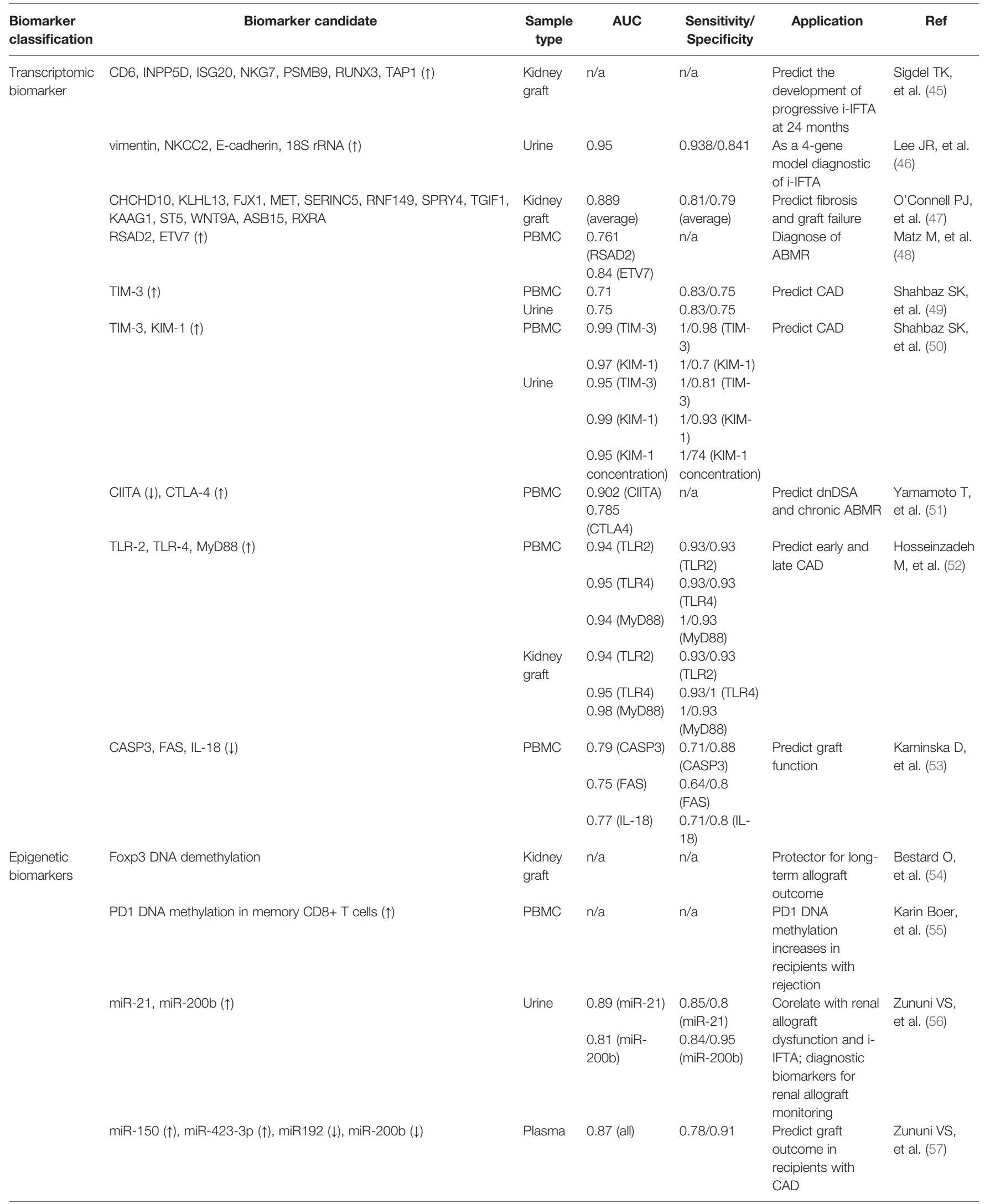


TABLE 1 | Continued

\begin{tabular}{|c|c|c|c|c|c|c|}
\hline $\begin{array}{l}\text { Biomarker } \\
\text { classification }\end{array}$ & Biomarker candidate & $\begin{array}{c}\text { Sample } \\
\text { type }\end{array}$ & AUC & $\begin{array}{l}\text { Sensitivity/ } \\
\text { Specificity }\end{array}$ & Application & Ref \\
\hline & miR21, miR-155, miR-142-3p ( $\uparrow)$ & Plasma & 0.82 (all) & $0.81 / 0.92$ & $\begin{array}{l}\text { Upregulate in } \\
\text { recipients with i- } \\
\text { IFTA; corelate with } \\
\text { renal allograft } \\
\text { dysfunction; can } \\
\text { be used for graft } \\
\text { monitoring }\end{array}$ & $\begin{array}{l}\text { Zununi VS, } \\
\text { et al. (58) }\end{array}$ \\
\hline & $\operatorname{miR}-148 a(\downarrow)$ & Plasma & 0.89 & $0.97 / 0.72$ & $\begin{array}{l}\text { Correlated with } \\
\text { renal function and } \\
\text { histological } \\
\text { grades; biomarker } \\
\text { of the progression } \\
\text { to i-IFTA }\end{array}$ & $\begin{array}{l}\text { Nariman- } \\
\text { Saleh-Fam Z, } \\
\text { et al. (60) }\end{array}$ \\
\hline & $\operatorname{miR}-142-5 p(\downarrow), \operatorname{miR}-486-5 p(\uparrow)$ & PBMC & $\mathrm{n} / \mathrm{a}$ & $\mathrm{n} / \mathrm{a}$ & $\begin{array}{l}\text { Predict chronic } \\
\text { ABMR }\end{array}$ & $\begin{array}{l}\text { Iwasaki K, } \\
\text { et al. (62) }\end{array}$ \\
\hline \multirow[t]{9}{*}{$\begin{array}{l}\text { Proteomic } \\
\text { biomarker }\end{array}$} & $\begin{array}{l}\text { V305_HUMAN_NTLYLNMNSLR, RL18_HUMAN_ILTFDQLALDSPK, } \\
\text { F151A_HUMAN_AVGPSLDLLR, TGFR2_HUMAN_LTAQCVAER, } \\
\text { LYAM1_HUMAN_AEIEYLEK, K2C8_HUMAN_LSELEAALQR, } \\
\text { F151A_HUMAN_TYTQAMVEK, PLGB_Human_AFQYHSK, } \\
\text { K1C19_HUMAN_ILGATIENSR, IBP7_HUMAN_GTCEQGPSIVTPPK, } \\
\text { LV102_HUMAN_WYQQLPGTAPK } \\
\text { DSRAD_Human_YLNTNPVGGLLEYAR, }\end{array}$ & Urine & 0.995 & $\mathrm{n} / \mathrm{a}$ & Predict CAD & $\begin{array}{l}\text { Sigdel TK, } \\
\text { et al. (63) }\end{array}$ \\
\hline & $\operatorname{PARP1}(\downarrow)$ & Serum & 0.871 & $\mathrm{n} / \mathrm{a}$ & $\begin{array}{l}\text { Predict AR and } \\
\text { chronic graft injury }\end{array}$ & $\begin{array}{l}\text { Srivastava M, } \\
\text { et al. (64) }\end{array}$ \\
\hline & & & $\begin{array}{l}0.8 \text { (CXCL10), } \\
0.82 \\
(C X C L 10 / C r)\end{array}$ & $\mathrm{n} / \mathrm{a}$ & $\begin{array}{l}\text { Predict mixed } \\
\text { rejection }\end{array}$ & \\
\hline & & & $\begin{array}{l}0.7 \text { (CXCL10), } \\
0.7 \text { (CXCL10) } \\
\text { Cr) }\end{array}$ & $\mathrm{n} / \mathrm{a}$ & Predict ABMR & \\
\hline & CXCL10/Cr ratio $(\uparrow)$ & Urine & $\begin{array}{l}0.81 \text { (sub- } \\
\text { clinical TCMR) }\end{array}$ & $\begin{array}{l}0.59 / 0.67 \\
\text { (subclinical } \\
\text { TCMR) }\end{array}$ & $\begin{array}{l}\text { Predict TCMR for } \\
\text { pediatric recipients }\end{array}$ & $\begin{array}{l}\text { Blydt-Hansen } \\
\text { TD, et al. (67) }\end{array}$ \\
\hline & & & $\begin{array}{l}0.88 \text { (clinical } \\
\text { TCMR) }\end{array}$ & $\begin{array}{l}0.77 / 0.6 \\
\text { (clinical } \\
\text { TCMR) }\end{array}$ & & \\
\hline & Vitronectin $(\uparrow)$ & Urine & 0.963 & $\mathrm{n} / \mathrm{a}$ & $\begin{array}{l}\text { Monitor fibrotic } \\
\text { changes in kidney } \\
\text { allograft }\end{array}$ & $\begin{array}{l}\text { Carreras- } \\
\text { Planella L, } \\
\text { et al. (68) }\end{array}$ \\
\hline & Properdin, sC5b-9 ( $\uparrow$ & Urine & $\mathrm{n} / \mathrm{a}$ & $\mathrm{n} / \mathrm{a}$ & $\begin{array}{l}\text { As risk factors of } \\
\text { graft failure }\end{array}$ & $\begin{array}{l}\text { Lammerts R, } \\
\text { et al. (69) }\end{array}$ \\
\hline & AZGP1 $(\uparrow)$ & Urine & 0.946 & $0.846 / 0.8$ & $\begin{array}{l}\text { Predict and } \\
\text { diagnose chronic } \\
\text { ABMR }\end{array}$ & $\begin{array}{l}\text { Jung HY, } \\
\text { et al. (70) }\end{array}$ \\
\hline
\end{tabular}


TABLE 1 | Continued

\begin{tabular}{|c|c|c|c|c|c|c|}
\hline $\begin{array}{l}\text { Biomarker } \\
\text { classification }\end{array}$ & Biomarker candidate & $\begin{array}{l}\text { Sample } \\
\text { type }\end{array}$ & AUC & $\begin{array}{l}\text { Sensitivity/ } \\
\text { Specificity }\end{array}$ & Application & Ref \\
\hline & $\beta 2$ microglobulin, NGAL, clusterin, KIM-1 ( $\uparrow)$ & Urine & $\mathrm{n} / \mathrm{a}$ & $\mathrm{n} / \mathrm{a}$ & $\begin{array}{l}\text { Predict chronic } \\
\text { allograft } \\
\text { nephropathy }\end{array}$ & $\begin{array}{l}\text { Cassidy } \mathrm{H} \text {, } \\
\text { et al. }(71)\end{array}$ \\
\hline \multirow[t]{7}{*}{$\begin{array}{l}\text { Metabolomic } \\
\text { biomarkers }\end{array}$} & Newly Synthesized DNA and ATP & PBMC & $\mathrm{n} / \mathrm{a}$ & $\mathrm{n} / \mathrm{a}$ & $\begin{array}{l}\text { Analyze } \\
\text { lymphocyte subset } \\
\text { activation } \\
\text { responses }\end{array}$ & $\begin{array}{l}\text { Sottong PR, } \\
\text { et al. (72) }\end{array}$ \\
\hline & $\begin{array}{l}\text { NAD, 1-MN, cholesterol sulfate, GABA, nicotinic acid, NADPH, } \\
\text { proline, spermidine, alpha-hydroxyhippuric acid }\end{array}$ & Urine & $\mathrm{n} / \mathrm{a}$ & $\mathrm{n} / \mathrm{a}$ & Predict TCMR & $\begin{array}{l}\text { Kalantari S, } \\
\text { et al. (73) }\end{array}$ \\
\hline & $\begin{array}{l}\text { Alanine, Citrate, Lactate, combined with urea or glucose or } \\
\text { glucutonate }\end{array}$ & Urine & 0.76 & $\mathrm{n} / \mathrm{a}$ & Diagnose AR & $\begin{array}{l}\text { Miriam B, } \\
\text { et al. (74) }\end{array}$ \\
\hline & $\begin{array}{l}\text { threitol, inositol, glucose, xylono-1, 5-lactone, xylitol, xylopyranoside, } \\
\text { 2,3-dihydroxybutanoic acid, glucitol, ribonic acid, octadecanoic acid, } \\
\text { phosphate }(\uparrow) \\
\text { fructose, glycolic acid, 3-hydroxyisovaleric acid }(\downarrow)\end{array}$ & Urine & $\mathrm{n} / \mathrm{a}$ & $0.867 / 0.677$ & Diagnose AR & $\begin{array}{l}\text { Long Zheng, } \\
\text { et al. (75) }\end{array}$ \\
\hline & $\begin{array}{l}\text { guanidoacetic acid, methylimidazoleacetic acid, dopamine }(\uparrow) \\
\text { 4-guanidinobutyric acid, L-tryptophan }(\downarrow)\end{array}$ & Urine & 0.926 & $0.9 / 0.846$ & Diagnose AR & $\begin{array}{l}\text { Kim S, et al. } \\
(76)\end{array}$ \\
\hline & Itaconate, kynurenine $(\uparrow)$ & $\begin{array}{l}\text { Kidney } \\
\text { graft }\end{array}$ & $\mathrm{n} / \mathrm{a}$ & $\mathrm{n} / \mathrm{a}$ & $\begin{array}{l}\text { Distinguish acute } \\
\text { cellular rejection } \\
\text { from IRI }\end{array}$ & $\begin{array}{l}\text { Beier UH, } \\
\text { et al. (77) }\end{array}$ \\
\hline & $\begin{array}{l}\text { glycine, glutaric acid, adipic acid, inulobiose, threose, sulfuric acid, } \\
\text { taurine, } N \text {-methylalanine, asparagine, 5-aminovaleric acid lactam, } \\
\text { myo-inositol }\end{array}$ & Urine & 0.985 & $0.929 / 0.963$ & Diagnose AR & $\begin{array}{l}\text { Sigdel TK, } \\
\text { et al. (78) }\end{array}$ \\
\hline \multirow[t]{6}{*}{$\begin{array}{l}\text { Cellular } \\
\text { biomarker }\end{array}$} & TEMRA/EM CD8 T cell ratio $(\uparrow)$ & PBMC & $\begin{array}{l}0.75 \text { (8 year } \\
\text { graft failure) } \\
0.79 \text { (11 year } \\
\text { graft failure) }\end{array}$ & $\mathrm{n} / \mathrm{a}$ & Predict graft failure & $\begin{array}{l}\text { Jacquemont } \\
\text { L, et al. (79) }\end{array}$ \\
\hline & CD154+ T-cytotoxic memory cells $(\uparrow)$ & PBMC & 0.968 & $0.923 / 0.846$ & $\begin{array}{l}\text { Predict rejections } \\
\text { (liver) }\end{array}$ & $\begin{array}{l}\text { Ashokkumar } \\
\text { C, et al. (80) }\end{array}$ \\
\hline & & PBMC & 0.938 & $1 / 0.88$ & Predict AR (kidney) & $\begin{array}{l}\text { Ashokkumar } \\
\text { C, et al. (81) }\end{array}$ \\
\hline & alloreactive memory IFN- $\gamma$-producing $T$ cells $(\uparrow)$ & PBMC & 0.725 & $0.8 / 0.64$ & $\begin{array}{l}\text { Predict subclinical } \\
\text { TCMR and DSA }\end{array}$ & $\begin{array}{l}\text { Crespo E, } \\
\text { et al. (82) }\end{array}$ \\
\hline & $\begin{array}{l}\text { Ratio of } T \text { follicular helper cells and } T \text { follicular regulatory cells }(\mathrm{TfC} / \mathrm{Tfr} \text { ) } \\
(\uparrow)\end{array}$ & PBMC & $\mathrm{n} / \mathrm{a}$ & $\mathrm{n} / \mathrm{a}$ & Risk factor of CAD & $\begin{array}{l}\text { Yan L, et al. } \\
\text { (83) }\end{array}$ \\
\hline & Myofibroblast & $\begin{array}{l}\text { Kidney } \\
\text { graft }\end{array}$ & $\mathrm{n} / \mathrm{a}$ & $\mathrm{n} / \mathrm{a}$ & Identify CR & $\begin{array}{l}\text { Liu YG, et al. } \\
(84)\end{array}$ \\
\hline
\end{tabular}

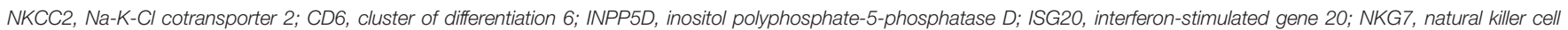

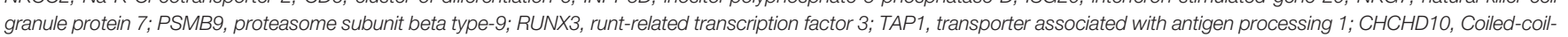

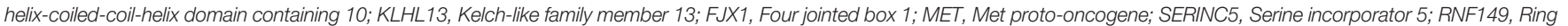

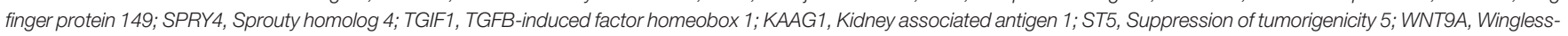

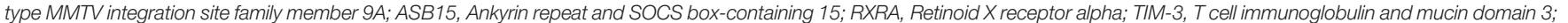

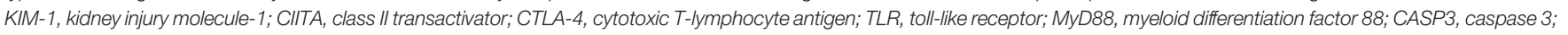

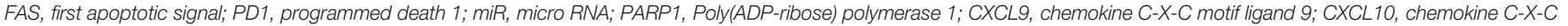

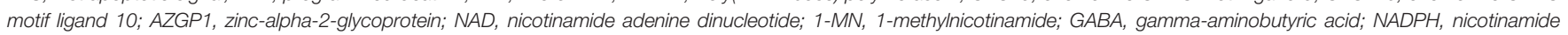

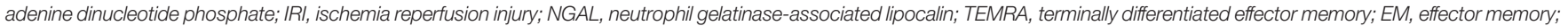

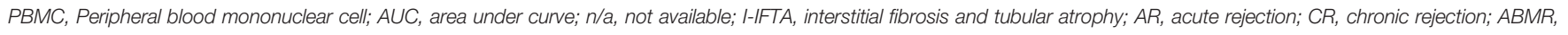
antibody-mediated rejection; TCMR, T cell-mediated rejection; CAD, chronic allograft dysfunction; dnDSA, de novo donor specific antibody.

differentiation, and migration of a variety of cell types, e.g. helper $\mathrm{T}$ cells $(90,91)$ or regulatory $\mathrm{T}$ cells $(54)$ and fibroblast $(92)$, which are implicated in allograft survival and kidney fibrosis. For example, Foxp3 demethylation at the $\mathrm{T}(\mathrm{reg})$-specific demethylation region positively correlates with numbers of intragraft Foxp3-expressing $\mathrm{T}$ cells in patients with subclinical rejection with i-IFTA via protocol biopsies; consequently, patients with more Foxp3+ T(reg) cells within graft infiltrates showed significantly better 5 -year graft function evolution than patients without Foxp3 + T(reg) cell infiltration (54). Boer et al. (55) studied DNA methylation (DNAm) of the pro-inflammatory cytokine interferon $\gamma(\mathrm{IFN} \gamma)$ and the inhibitory receptor programmed death 1 (PD1) in naive and memory CD8+ T cell subsets in kidney transplant recipients. Increased DNAm of IFN- $\gamma$ and PD1 was observed in memory CD8+ T cells in kidney transplant recipients 3 months after transplantation, regardless of a rejection episode or not, suggesting that it was a non-specific change associated with transplant surgery or use of immunosuppressive drugs. However, PD1 methylation in the CD27- memory CD8+ T cells was more prominently increased in recipients with rejection episode than those without. In a more recent study concerning the role of DNAm in progression of IFTA in renal biopsies, normal allograft 
biopsies at 2-years post-transplantation showed similar DNAm patterns comparable to preimplantation biopsies, whereas persistent differentially methylation was associated with progression of allografts to chronic renal allograft dysfunction (93). Epigenetic mechanisms such as hypomethylation could directly boost and indirectly modulate their expression by controlling miRNAs (93). Recent studies have revealed that miR21 and miR200b expression in urine are associated with IFTA and CAD (56), while circulating miR-150, miR192, miR-200b, and miR-423-3p in plasma are related to IFTA (57). Meanwhile, expression of miR21, miR-155, and miR-142-3p was upregulated in the plasma of patients with IFTA (58), while miR145-5p and miR-148a were down-regulated (59, 60). Another study showed that expression of miR-142-3p was up-regulated, whereas miR-204 and miR-211 were down-regulated both in urine and kidney graft of recipients with CAD-IFTA (61). In addition, up-regulation of miR142-5p, and down-regulation of miR-486-5p may serve as biomarkers for early detection of chronic ABMR (62). These markers could, therefore, be considered as potential markers for CAD.

\section{Proteomic Biomarkers}

Scores of non-invasive proteomic biomarkers of CKTR are generated using high-throughput proteomic techniques, such as liquid chromatography-mass spectrometry (LC-MS), isobaric tag for relative and absolute quantitation (iTRAQ), protein microarray, and bead-based immunoassay. Studies investigating non-invasive proteomic biomarkers in urine and blood (94), have discovered unique protein sets valuable for differential diagnosis. For example, one study on a set of 245 urine samples from a pediatric and young adult kidney allograft recipient cohort, identified 35 proteins that could discriminate three types of graft injury, 11 peptides for acute rejection, 12 urinary peptides for chronic allograft nephropathy and 12 peptides for BK virus nephritis (63). Metzger et al. (95) validated a multi-marker urinary peptide classifier constructed from capillary electrophoresis mass spectrometry (CE-MS) peptide spectra of urine from a training set of 39 allograft patients to discriminate TCMR from healthy allografts. Srivastava et al. $(64,65)$ identified that the up-expression of urine ANXA11, Integrin $\alpha 3$, Integrin $\beta 3$ and TNF- $\alpha$, and the downregulation of serum PARP1 could be used as candidate proteomic biomarkers for kidney allograft rejection. Furthermore, several proteins, some chemokines and cytokines in blood and urine are also identified as biomarkers for diagnosing CKTR and predicting graft outcomes (66-71). Several recent efforts have established urinary C-X-C motif chemokine 9 (CXCL9) and CXCL10 as reliable biomarkers for subclinical allograft rejection and for guiding the post-transplant management $(66,67)$. A recent study shows that platelets contain a wide array of mediators that could potentially promote acute and chronic $\operatorname{ABMR}(96,97)$. In fact, platelet factor 4 (PF4, also known as CXCL4), the most abundant platelet-related mediator detected in the allograft with large quantities, has multiple consequences on allografts, one of which is to promote monocytes survival and macrophage differentiation (98), predicting poorer graft outcomes (99).

\section{Metabolomic Biomarkers}

Metabolomics is a rapidly emerging research field that involves comprehensive analysis of all metabolites in a single biological sample (100) and has recently gained tremendous interest in the biomarker study in organ transplantation. Compared to proteomic or transcriptomic markers, metabolomic biomarkers may be more precise in reflecting cellular functions (101). Metabolomics can be used in two ways: intensively analyzing and identifying individual metabolites; or using pattern recognition to record spectral patterns and intensities instead of recording individual molecules (100, 102). Researchers recommend that metabolomic markers improve observing rejection and other organ injuries (103). In children, urinary metabolomics improved detection of borderline TCMR and demonstrated promise in ABMR (104). Measuring adenosine triphosphate (ATP) generation by mitogen-stimulated CD4 lymphocytes (ImmuKnow assay) is an FDA-approved biomarker potentially effective in transplant recipients (72). In a randomized prospective study, based on immune function values determined by ImmuKnow assay, one-year patient survival was markedly improved and infection rates were reduced in the group receiving ATP release biomarker-guided immunosuppressant regulation (105). In a recent study, a panel of nine differential metabolites in urine were identified as novel potential metabolite biomarkers of TCMR (73). The metabolomic biomarkers that considered as potential markers for rejection episodes are listed in Table $\mathbf{1}$ (72-78).

\section{Cellular Biomarkers}

There has been significant attentions drawn to quantify alloreactive CD8+ $\mathrm{T}$ cells as potential cellular biomarkers of rejection $(25,79,106)$, or tolerance (107). Ashokkumar et al. (80) found that allospecific CD154+ T-cytotoxic memory cells were associated with rejection risk in liver transplant recipients. Limited data showed that an increase in CD154+ subset is implicated in acute kidney transplant rejection (81). Resent studies showed that monitoring alloreactive memory IFN- $\gamma$ producing $\mathrm{T}$ cells could assess subclinical TCMR and predict de novo DSA (82), while ratio of $\mathrm{T}$ follicular helper cells and $\mathrm{T}$ follicular regulatory cells ( $\mathrm{Tfc} / \mathrm{Tfr}$ ) was an independent risk factor for CAD (83). However, multicenter validation of its diagnostic/ prognostic biomarker utility in CKTR remains to be determined (108). Both macrophages and NK cells are implicated in chronic rejection $(21,109-111)$. However, it remains to be determined whether a specific subset of macrophages or NK cells could be served as cellular markers for CKTR. Recently, single-cell sequencing technologies have been rapidly developed and have evolved as a power tool for unbiased assessments of genomic, epigenomic, and transcriptomic profiling at the single-cell level. Compared with traditional sequencing technology, single-cell technologies have the advantages of detecting heterogeneity among individual cells, distinguishing a small number of cells, and delineating cell maps $(112,113)$. Using scRNA-seq technique, Liu et al. revealed multiple novel subsets of immune cells, including five subclasses of NKT cells, two subtypes in memory $\mathrm{B}$ cells, a classic CD14+ group and a nonclassical CD16+ group in 
monocytes, in patients with CKTR. They also identified a novel subpopulation [myofibroblasts (MyoF)] in fibroblasts, which express collagen and extracellular matrix components in CKTR group (84). While still in its early infancy, scRNA-seq is considered as diagnostic tool for identifying cellular and molecular biomarkers specific for CKTR. With improved understanding of cellular mechanisms underlying CKTR and advances in the multi-color flow cytometry analyses combining with more recent development of single-cell genomics studies, it is conceivable that more precise cellular biomarkers will be identified for CKTR.

Several considerations ought to be adequately addressed before these biomarkers can be regularly used in the clinical practice for kidney transplants (114-116). First, sensitivity, specificity, positive and negative predictive values must be considered, and receiver operating characteristic (ROC) curves need to be thoroughly assessed for their clinical utility. Secondly, integration of different biomarkers is necessary for accurate diagnosis. Thirdly, robust validation studies and standardization of measurements are required to identify new biomarkers. Finally, timing required for generating results and cost of assessment should be reasonable.

\section{NEW THERAPIES FOR THE TREATMENT OF CKTR}

Chronic active ABMR is the most widely recognized cause of allograft failure (117), whereas TCMR usually exists in a mixed rejection phenotype (118). Given current understanding that that chronic active TCMR is often associated with insufficient immunosuppression, TCMR treatment has been directed to increasing doses and types of anti-T cell immunosuppressive agents such as combinations of therapies with basiliximab, everolimus in addition to tacrolimus (119). Numerous therapies have been used in the clinical setting, mostly focusing on chronic active ABMR. The strategies include plasmapheresis, intravenous immunoglobulin (IVIG), CD20 antibody (rituximab), proteasome inhibitor (bortezomib) (120-122) and anti-complement monoclonal antibody (eculizumab), single or combined therapies $(123,124)$. Their therapeutic effectiveness in treatment of chronic active ABMR have been evaluated in recent randomized controlled trials and results have been extensively reviewed (125), suggesting limited success being achieved by using these agents alone or in combination despite their effectiveness in treating acute ABMR. Through biomarker discovery, understanding of CKTR has been tremendously improved over the last five years. Recognition of biological similarities shared by CKTR, cancer immunology and autoimmune diseases has led to frontier investigations in repurposing of several treatment strategies from cancer therapy or autoimmune diseases to ABMR. IL-6/IL-6R blockade (Tocilizumab), C1 esterase inhibitor (C1 INH), and Blymphocyte stimulator (BLyS) inhibitor (Belimumab) are among those that have been tested for their therapeutic potentials in mitigating $\mathrm{ABMR}$ and have shown promising results as described below and summarized in Table 2 .

\section{IL-6/IL-6R Blockade}

IL-6 is a pleotropic cytokine associated to many facets of innate and adaptive immunity, which plays an important role in DSA generation and chronic ABMR, including its effects on B cell immunity and antibody-producing plasma cells, as well as the balance between effector and regulatory $\mathrm{T}$ cells (130). Blockade of the IL-6/IL-6R axis with Tocilizumab, anti-interleukin-6 receptor monoclonal antibody has been well-established for the treatment of rheumatoid arthritis (131), and is recently

TABLE 2 | Clinical trials - new therapies for chronic ABMR after kidney transplantation.

\begin{tabular}{|c|c|c|c|c|c|c|c|}
\hline Trial design & Inclusion criteria & Test therapeutics & $\begin{array}{c}\text { Other Immuno } \\
\text { suppression }\end{array}$ & Patients & $\begin{array}{l}\text { Follow } \\
\text { up }\end{array}$ & Major results & Ref \\
\hline $\begin{array}{l}\text { single center, } \\
\text { open-label } \\
\text { case study, } \\
\text { historical } \\
\text { control }\end{array}$ & $\begin{array}{l}\text { chronic ABMR, } \\
\text { DSA+, TG }\end{array}$ & $\begin{array}{l}\text { Tocilizumab }(8 \mathrm{mg} / \mathrm{kg} \text { monthly, } \\
\text { maximal dose } 800 \mathrm{mg} \text { for } 6-25 \\
\text { months) }\end{array}$ & Tac/MMF/Pred & 36 & 6 years & $\begin{array}{l}\text { reduction in DSAs and } \\
\text { stabilization of renal function at } 2 \\
\text { years; graft survival rate of } 80 \% \text {, } \\
\text { patient survival rate of } 91 \% \text { at } 6 \\
\text { years }\end{array}$ & $\begin{array}{l}\text { Choi J, et al. } \\
(126)\end{array}$ \\
\hline $\begin{array}{l}\text { randomized } \\
\text { controlled } \\
\text { trials }\end{array}$ & ABMR, DSA+ & $\begin{array}{l}\text { C1 INH (5000 } U \text { on day } 1 \text { of } \\
\text { ABMR, } 2500 \cup \text { on days } 3,5,7 \text {, } \\
9,11 \text {, and } 13) \text { add-on standard } \\
\text { of care (PP+IVIG+/- anti-CD20) }\end{array}$ & $\mathrm{n} / \mathrm{a}$ & $\begin{array}{l}18 \\
\text { (treatment: } \\
\mathrm{n}=9 \\
\text { placebo: } \\
\mathrm{n}=9 \text { ) }\end{array}$ & $\begin{array}{l}6 \\
\text { months }\end{array}$ & $\begin{array}{l}\text { reduction of transplant } \\
\text { glomerulopathy }\end{array}$ & $\begin{array}{l}\text { Montgomery } \\
\text { RA, et al. } \\
(127)\end{array}$ \\
\hline $\begin{array}{l}\text { single center, } \\
\text { observational } \\
\text { study, } \\
\text { historical } \\
\text { control }\end{array}$ & $\begin{array}{l}\text { refractory active } \\
\text { ABMR with acute } \\
\text { allograft dysfunction, } \\
\text { DSA }>3000 \mathrm{MFI}, \mathrm{g} \\
\text { +ptc } \geq 2\end{array}$ & $\begin{array}{l}\text { C1 INH (20 units/kg on days } 1 \text {, } \\
2 \text {, and } 3 \text { and then twice weekly; } \\
\text { IVIG at } 2 \mathrm{~g} / \mathrm{kg} \text { every month for } 6 \\
\text { months }\end{array}$ & Tac/MMF/Pred & 6 & $\begin{array}{l}6 \\
\text { months }\end{array}$ & $\begin{array}{l}\text { improvement in eGFR, reduced } \\
\text { DSA; no change in histological } \\
\text { features }\end{array}$ & $\begin{array}{l}\text { Viglietti D, } \\
\text { et al. (128) }\end{array}$ \\
\hline $\begin{array}{l}\text { randomized } \\
\text { controlled } \\
\text { trials }\end{array}$ & $\begin{array}{l}\text { adult patient receiving } \\
\text { a kidney transplant }\end{array}$ & $\begin{array}{l}\text { Belimumab (10 mg/kg on day } 0 \text {, } \\
14, \text { and } 28 \text {, and then every } 4 \\
\text { weeks for a total of } 7 \text { infusions) }\end{array}$ & Tac/MMF/Pred & $\begin{array}{l}28 \\
\text { (treatment: } \\
n=14 ; \\
\text { placebo: } \\
n=14 \text { ) }\end{array}$ & $\begin{array}{l}6 \\
\text { months }\end{array}$ & $\begin{array}{l}\text { similar proportions of adverse } \\
\text { events; no change in the number } \\
\text { of naive B cells }\end{array}$ & $\begin{array}{l}\text { Banham GD, } \\
\text { et al. (129) }\end{array}$ \\
\hline
\end{tabular}

TG, transplant glomerulopathy; Tac, tacrolimus; MMF, mycophenolate mofetil; Pred, prednisone; n/a, not available. 
considered as a new therapy to prevent ABMR progression (126). It has been shown that tocilizumab markedly reduced DSAs and stabilized renal function at 2 years post-transplant, suggesting a therapeutic effect of tocilizumab in ABMR. Tocilizumab has also been evaluated in combination with IVIG and rituximab for patients who failed standard desensitization, and it appeared well tolerated and safe (132). However, there is still a lack of randomized controlled trials to systematically evaluate the efficacy and safety of tocilizumab to date. Another new inhibitor for IL-6/IL-6R axis is clazakizumab, a genetically engineered humanized monoclonal antibody directed against IL-6. Two pilot trials (NCT03444103, NCT03380377) (132134) and a large multicenter trial evaluating clazakizumab in late/chronic ABMR (NCT03744910) (135) are underway.

\section{C1 Esterase Inhibitor (C1 INH)}

Since the efficacy of C5 blockade in late ABMR is limited (123, 124), blockade of early complement pathway at the level of key component $\mathrm{C} 1$ has attracted a great deal of attention. One potential strategy being studied is the use of $\mathrm{C} 1 \mathrm{INH}$, which has been used to prevent and/or treat attacks of hereditary angioedema for years and has an established safety record (136). C1-INH is a serum protease inhibitor that binds covalently and inactivates $\mathrm{C} 1 \mathrm{r}, \mathrm{C} 1 \mathrm{~s}$, and mannan-binding protein-associated proteases $(136,137)$. In a double-blind RCT, C1-INH was tested as a treatment for biopsy-proven ABMR. Both $\mathrm{C} 1-\mathrm{INH}$ and placebo groups showed improvements in early follow-up biopsies. However, in a subset of patients with late follow-up biopsies (6 months), a decreased rate of transplant glomerulopathy was seen in C1-INH treated group, accompanied by improved graft function, suggesting $\mathrm{C} 1-\mathrm{NIH}$ may be effective in preventing the development of chronic injury (127). In a prospective, single-arm pilot clinical trail, C1-INH was added to IVIG to treat refractory acute ABMR. In comparison with historical controls, patients treated with $\mathrm{C} 1-\mathrm{INH}$ showed decreased $\mathrm{C} 4 \mathrm{~d}$ deposition and improved renal function, whereas microcirculatory damage still persisted (glomerulitis, peritubular capillaritis, and allograft glomerulopathy) (128). Currently, a large multicenter clinical trials evaluating C1-INH added to standard treatment of ABMR (NCT02547220) (138) is underway, while another clinical trial evaluating $\mathrm{C} 1-\mathrm{NIH}$ for the treatment of refractory AMR (NCT03221842) in renal transplant recipients (139) is also ongoing.

\section{Inhibition of B-lymphocyte Stimulator}

B-lymphocyte stimulator (BLyS) is a critical cytokine that enhances B cell and plasma cell survival (140). Targeting BLyS has recently driven increasing interest in transplant by modulating B cell alloimmunity. Belimumab, a humanized anti-BLyS antibody,

\section{REFERENCES}

1. Kasiske BL, Andany MA, Danielson B. A Thirty Percent Chronic Decline in Inverse Serum Creatinine Is an Excellent Predictor of Late Renal Allograft Failure. Am J Kidney Dis (2002) 39:762-8. doi: 10.1053/ ajkd.2002.31996 which has shown therapeutic efficacy in systemic lupus erythematosus (141), has now been applied in organ transplantation. In a double-blind, randomized, placebocontrolled phase 2 trial, belimumab was evaluated in 28 kidney transplant recipients (129). The findings revealed that treatment of belimumab showed no effect on reducing the number of naive $B$ cells from baseline to 24 weeks after transplant. However, the activated memory B cells and plasmablasts were significantly reduced, and tissue-specific antibodies in serum were lowered. In addition, treatment with belimumab modulated the $\mathrm{B}$ cell profile towards a regulatory profile by changing the IL-10/IL- 6 ratio. In parallel, genes coding for IgG and markers of T cell proliferation were reduced (129). To date, there is still lack of clinical trial using belimumab to treat chronic rejection. In a murine chronic ABMR kidney transplant model, blockade of APRIL/BLyS by TAC-Ig resulted in decreased antinuclear antibody (ANA) and disruption of splenic germinal center architecture, but have no significant difference in lymphocyte infiltration and kidney graft pathology compared with control grafts, which may be due to the absence of T cell immunosuppression (142).

\section{CONCLUSION}

Discovery of novel earlier diagnostic biomarkers will not only allows designing individualized therapy for timely therapeutic intervention, but also further advance understanding of pathogenesis of CKTR. Although many biomarkers listed in Table 1 still require validation and standardization in several independent cohorts, considerable progress has been made in recent years $(115,116,143)$. The management of CKTR remains a daunting task due to the complex pathogenesis of CKTR and irreversibility at the time of diagnosis. Nevertheless, several promising therapies have been in robust intervention trials with promising results. With the emergence of new technologies, such as single cell genomics, computational biology along with artificial intelligence-based assistance, it is conceivable that more specific biomarkers and therapeutic targets for CKTR will be identified and translated into the clinical practice in the very near future.

\section{AUTHOR CONTRIBUTIONS}

$\mathrm{XL}$ and XZ: participated in manuscript preparation and writing. JM, LG, and JL: provided suggestion and edits. ZZ conceptualized, wrote, and revised manuscript All authors contributed to the article and approved the submitted version.

2. Hara S. Current Pathological Perspectives on Chronic Rejection in Renal Allografts. Clin Exp Nephrol (2017) 21:943-51. doi: 10.1007/s10157-016-1361-x

3. Stegall MD, Park WD, Larson TS, Gloor JM, Cornell LD, Sethi S, et al. The Histology of Solitary Renal Allografts At 1 and 5 Years After Transplantation. Am J Transplant (2011) 11:698-707. doi: 10.1111/j.16006143.2010.03312.x 
4. Shiu KY, Stringer D, McLaughlin L, Shaw O, Brookes P, Burton H, et al. Effect of Optimized Immunosuppression (Including Rituximab) on AntiDonor Alloresponses in Patients With Chronically Rejecting Renal Allografts. Front Immunol (2020) 11:79. doi: 10.3389/fimmu.2020.00079

5. Loupy A, Haas M, Roufosse C, Naesens M, Adam B, Afrouzian M, et al. The Banff 2019 Kidney Meeting Report (I): Updates on and Clarification of Criteria for T Cell- and Antibody-Mediated Rejection. Am J Transplant (2020) 20:2318-31. doi: 10.1111/ajt.15898

6. Haas M, Loupy A, Lefaucheur C, Roufosse C, Glotz D, Seron D, et al. The Banff 2017 Kidney Meeting Report: Revised Diagnostic Criteria for Chronic Active T Cell-Mediated Rejection, Antibody-Mediated Rejection, and Prospects for Integrative Endpoints for Next-Generation Clinical Trials. Am J Transplant (2018) 18:293-307. doi: 10.1111/ajt.14625

7. Tsuji T, Iwasaki S, Makita K, Imamoto T, Ishidate N, Mitsuke A, et al. Preceding T-Cell-Mediated Rejection Is Associated With the Development of Chronic Active Antibody-Mediated Rejection by De Novo DonorSpecific Antibody. Nephron (2020) 144:13-7. doi: 10.1159/000512659

8. Everly MJ, Everly JJ, Arend LJ, Brailey P, Susskind B, Govil A, et al. Reducing De Novo Donor-Specific Antibody Levels During Acute Rejection Diminishes Renal Allograft Loss. Am J Transplant (2009) 9:1063-71. doi: 10.1111/j.1600-6143.2009.02577.x

9. Halloran PF, Chang J, Famulski K, Hidalgo LG, Salazar ID, Merino LM, et al. Disappearance of T Cell-Mediated Rejection Despite Continued Antibody-Mediated Rejection in Late Kidney Transplant Recipients. J Am Soc Nephrol (2015) 26:1711-20. doi: 10.1681/ASN.2014060588

10. Nankivell BJ, Shingde M, Keung KL, Fung CL, Borrows RJ, O'Connell PJ, et al. The Causes, Significance and Consequences of Inflammatory Fibrosis in Kidney Transplantation: The Banff i-IFTA Lesion. Am J Transplant (2018) 18:364-76. doi: 10.1111/ajt.14609

11. Roos-van GM, Scholten EM, Lelieveld PM, Rowshani AT, Baelde HJ, Bajema IM, et al. Molecular Comparison of Calcineurin Inhibitor-Induced Fibrogenic Responses in Protocol Renal Transplant Biopsies. J Am Soc Nephrol (2006) 17:881-8. doi: 10.1681/ASN.2005080891

12. Lefaucheur C, Loupy A. Antibody-Mediated Rejection of Solid-Organ Allografts. N Engl J Med (2018) 379:2580-2. doi: 10.1056/NEJMc1813976

13. Thomas KA, Valenzuela NM, Reed EF. The Perfect Storm: HLA Antibodies, Complement, FcgammaRs, and Endothelium in Transplant Rejection. Trends Mol Med (2015) 21:319-29. doi: 10.1016/j.molmed.2015.02.004

14. Reese SR, Wilson NA, Huang Y, Ptak L, Degner KR, Xiang D, et al. B Cell Deficiency Attenuates Transplant Glomerulopathy in a Rat Model of Chronic Active Antibody-mediated Rejection. Transplantation (2020). doi: 10.1097/TP.0000000000003530

15. Zhang R. Donor-Specific Antibodies in Kidney Transplant Recipients. Clin J Am Soc Nephrol (2018) 13:182-92. doi: 10.2215/CJN.00700117

16. Dieplinger G, Everly MJ, Briley KP, Haisch CE, Bolin P, Maldonado AQ, et al. Onset and Progression of De Novo Donor-Specific Anti-Human Leukocyte Antigen Antibodies After BK Polyomavirus and Preemptive Immunosuppression Reduction. Transpl Infect Dis (2015) 17:848-58. doi: 10.1111/tid.12467

17. De Keyzer K, Van Laecke S, Peeters P, Vanholder R. Human Cytomegalovirus and Kidney Transplantation: A Clinician's Update. Am J Kidney Dis (2011) 58:118-26. doi: 10.1053/j.ajkd.2011.04.010

18. Sablik KA, Jordanova ES, Pocorni N, Clahsen-van GM, Betjes M. Immune Cell Infiltrate in Chronic-Active Antibody-Mediated Rejection. Front Immunol (2019) 10:3106. doi: 10.3389/fimmu.2019.03106

19. Venner JM, Hidalgo LG, Famulski KS, Chang J, Halloran PF. The Molecular Landscape of Antibody-Mediated Kidney Transplant Rejection: Evidence for NK Involvement Through CD16a Fc Receptors. Am J Transplant (2015) 15:1336-48. doi: 10.1111/ajt.13115

20. Parkes MD, Halloran PF, Hidalgo LG. Evidence for CD16a-Mediated Nk Cell Stimulation in Antibody-Mediated Kidney Transplant Rejection. Transplantation (2017) 101:e102-11. doi: 10.1097/TP.0000000000001586

21. Hirohashi T, Chase CM, Della PP, Sebastian D, Alessandrini A, Madsen JC, et al. A Novel Pathway of Chronic Allograft Rejection Mediated by NK Cells and Alloantibody. Am J Transplant (2012) 12:313-21. doi: 10.1111/j.16006143.2011.03836.x

22. Ge S, Chu M, Choi J, Louie S, Vo A, Jordan SC, et al. Imlifidase Inhibits Hla Antibody-mediated Nk Cell Activation and Antibody-Dependent Cell-
Mediated Cytotoxicity (Adcc) In Vitro. Transplantation (2020) 104:15749. doi: 10.1097/TP.0000000000003023

23. Yazdani S, Callemeyn J, Gazut S, Lerut E, de Loor H, Wevers M, et al. Natural Killer Cell Infiltration Is Discriminative for Antibody-Mediated Rejection and Predicts Outcome After Kidney Transplantation. Kidney Int (2019) 95:188-98. doi: 10.1016/j.kint.2018.08.027

24. Lefaucheur C, Gosset C, Rabant M, Viglietti D, Verine J, Aubert O, et al. T Cell-Mediated Rejection Is a Major Determinant of Inflammation in Scarred Areas in Kidney Allografts. Am J Transplant (2018) 18:377-90. doi: 10.1111/ ajt.14565

25. Curci C, Sallustio F, Serino G, De Palma G, Trpevski M, Fiorentino M, et al. Potential Role of Effector Memory T Cells in Chronic T Cell-Mediated Kidney Graft Rejection. Nephrol Dial Transplant (2016) 31:2131-42. doi: 10.1093/ndt/gfw245

26. Benichou G, Gonzalez B, Marino J, Ayasoufi K, Valujskikh A. Role of Memory T Cells in Allograft Rejection and Tolerance. Front Immunol (2017) 8:170. doi: 10.3389/fimmu.2017.00170

27. Halloran PF. T Cell-Mediated Rejection of Kidney Transplants: A Personal Viewpoint. Am J Transplant (2010) 10:1126-34. doi: 10.1111/j.16006143.2010.03053.x

28. Stegall MD, Gaston RS, Cosio FG, Matas A. Through a Glass Darkly: Seeking Clarity in Preventing Late Kidney Transplant Failure. J Am Soc Nephrol (2015) 26:20-9. doi: 10.1681/ASN.2014040378

29. Kasiske BL, Zeier MG, Chapman JR, Craig JC, Ekberg H, Garvey CA, et al. KDIGO Clinical Practice Guideline for the Care of Kidney Transplant Recipients: A Summary. Kidney Int (2010) 77:299-311. doi: 10.1038/ ki.2009.377

30. Ivanyi B. Transplant Capillaropathy and Transplant Glomerulopathy: Ultrastructural Markers of Chronic Renal Allograft Rejection. Nephrol Dial Transplant (2003) 18:655-60. doi: 10.1093/ndt/gfg139

31. Zhang Q, Liang LW, Gjertson DW, Lassman C, Wilkinson AH, Kendrick E, et al. Development of Posttransplant Antidonor HLA Antibodies is Associated With Acute Humoral Rejection and Early Graft Dysfunction. Transplantation (2005) 79:591-8. doi: 10.1097/01.TP.0000155246.52249.AC

32. Scornik JC, Guerra G, Schold JD, Srinivas TR, Dragun D, Meier-Kriesche HU. Value of Posttransplant Antibody Tests in the Evaluation of Patients With Renal Graft Dysfunction. Am J Transplant (2007) 7:1808-14. doi: 10.1111/j.1600-6143.2007.01855.x

33. Wiebe C, Nickerson P. Posttransplant Monitoring of De Novo Human Leukocyte Antigen Donor-Specific Antibodies in Kidney Transplantation. Curr Opin Organ Transplant (2013) 18:470-7. doi: 10.1097/ MOT.0b013e3283626149

34. Everly MJ, Rebellato LM, Haisch CE, Ozawa M, Parker K, Briley KP, et al. Incidence and Impact of De Novo Donor-Specific Alloantibody in Primary Renal Allografts. Transplantation (2013) 95:410-7. doi: 10.1097/ TP.0b013e31827d62e3

35. Loupy A, Lefaucheur C, Vernerey D, Prugger C, Duong VHJ, Mooney N, et al. Complement-Binding Anti-HLA Antibodies and Kidney-Allograft Survival. N Engl J Med (2013) 369:1215-26. doi: 10.1056/NEJMoa1302506

36. Radermacher J, Mengel M, Ellis S, Stuht S, Hiss M, Schwarz A, et al. The Renal Arterial Resistance Index and Renal Allograft Survival. $N$ Engl J Med (2003) 349:115-24. doi: 10.1056/NEJMoa022602

37. Kramann R, Frank D, Brandenburg VM, Heussen N, Takahama J, Kruger T, et al. Prognostic Impact of Renal Arterial Resistance Index Upon Renal Allograft Survival: The Time Point Matters. Nephrol Dial Transplant (2012) 27:3958-63. doi: 10.1093/ndt/gfr772

38. Schwenger V, Korosoglou G, Hinkel UP, Morath C, Hansen A, Sommerer C, et al. Real-Time Contrast-Enhanced Sonography of Renal Transplant Recipients Predicts Chronic Allograft Nephropathy. Am J Transplant (2006) 6:609-15. doi: 10.1111/j.1600-6143.2005.01224.x

39. Beck-Tolly A, Eder M, Beitzke D, Eskandary F, Agibetov A, Lampichler K, et al. Magnetic Resonance Imaging for Evaluation of Interstitial Fibrosis in Kidney Allografts. Transplant Direct (2020) 6:e577. doi: 10.1097/ TXD.0000000000001009

40. Solez K, Colvin RB, Racusen LC, Sis B, Halloran PF, Birk PE, et al. Banff '05 Meeting Report: Differential Diagnosis of Chronic Allograft Injury and Elimination of Chronic Allograft Nephropathy ('Can'). Am J Transplant (2007) 7:518-26. doi: 10.1111/j.1600-6143.2006.01688.x 
41. Haas M, Sis B, Racusen LC, Solez K, Glotz D, Colvin RB, et al. Banff 2013 Meeting Report: Inclusion of c4d-Negative Antibody-Mediated Rejection and Antibody-Associated Arterial Lesions. Am J Transplant (2014) 14:27283. doi: 10.1111/ajt.12590

42. Quaglia M, Merlotti G, Guglielmetti G, Castellano G, Cantaluppi V. Recent Advances on Biomarkers of Early and Late Kidney Graft Dysfunction. Int J Mol Sci (2020) 21:5404. doi: 10.3390/ijms21155404

43. Califf RM. Biomarker Definitions and Their Applications. Exp Biol Med (Maywood) (2018) 243:213-21. doi: 10.1177/1535370217750088

44. Salvadori M, Tsalouchos A. Biomarkers in Renal Transplantation: An Updated Review. World J Transplant (2017) 7:161-78. doi: 10.5500/ wjt.v7.i3.161

45. Sigdel TK, Bestard O, Tran TQ, Hsieh SC, Roedder S, Damm I, et al. A Computational Gene Expression Score for Predicting Immune Injury in Renal Allografts. PLoS One (2015) 10:e138133. doi: 10.1371/journal.pone.0138133

46. Lee JR, Muthukumar T, Dadhania D, Ding R, Sharma VK, Schwartz JE, et al. Urinary Cell mRNA Profiles Predictive of Human Kidney Allograft Status. Immunol Rev (2014) 258:218-40. doi: 10.1111/imr.12159

47. O’Connell PJ, Zhang W, Menon MC, Yi Z, Schroppel B, Gallon L, et al. Biopsy Transcriptome Expression Profiling to Identify Kidney Transplants At Risk of Chronic Injury: A Multicentre, Prospective Study. Lancet (2016) 388:983-93. doi: 10.1016/S0140-6736(16)30826-1

48. Matz M, Heinrich F, Zhang Q, Lorkowski C, Seelow E, Wu K, et al. The Regulation of Interferon Type I Pathway-Related Genes RSAD2 and ETV7 Specifically Indicates Antibody-Mediated Rejection After Kidney Transplantation. Clin Transplant (2018) 32:e13429. doi: 10.1111/ctr.13429

49. Shahbaz SK, Barabadi M, Ahmadpour P, Pourrezagholi F, Nafar M, Foroughi F, et al. Sequential Monitoring of TIM-3 mRNA Expression in Blood and Urine Samples of Renal Transplant Recipients. Transpl Immunol (2019) 54:9-16. doi: 10.1016/j.trim.2018.10.007

50. Shahbaz SK, Pourrezagholi F, Barabadi M, Foroughi F, Hosseinzadeh M, Ahmadpoor P, et al. High Expression of TIM-3 and KIM-1 in Blood and Urine of Renal Allograft Rejection Patients. Transpl Immunol (2017) 4344:11-20. doi: 10.1016/j.trim.2017.07.002

51. Yamamoto T, Iwasaki K, Murotani K, Takeda A, Futamura K, Okada M, et al. Peripheral Blood Immune Response-Related Gene Analysis for Evaluating the Potential Risk of Chronic Antibody-Mediated Rejection. Hum Immunol (2018) 79:432-8. doi: 10.1016/j.humimm.2018.03.012

52. Hosseinzadeh M, Ahmadpoor P, Yekaninejad MS, Pourrezagholi F, Foroughi F, Ghorbanpour M, et al. Expression Patterns of Toll Like Receptor (TLR)-2, TLR-4 and Myeloid Differentiation Primary Response Gene 88 (MYD88) in Renal Transplant Patients Developing Allograft Dysfunction; a Cohort Study. Transpl Immunol (2018) 48:26-31. doi: 10.1016/j.trim.2018.02.005

53. Kaminska D, Koscielska-Kasprzak K, Chudoba P, Mazanowska O, Banasik M, Zabinska M, et al. Pretransplant Immune- and Apoptosis-Related Gene Expression is Associated With Kidney Allograft Function. Mediators Inflamm (2016) 2016:8970291. doi: 10.1155/2016/8970291

54. Bestard O, Cunetti L, Cruzado JM, Lucia M, Valdez R, Olek S, et al. Intragraft Regulatory T Cells in Protocol Biopsies Retain Foxp3 Demethylation and are Protective Biomarkers for Kidney Graft Outcome. Am J Transplant (2011) 11:2162-72. doi: 10.1111/j.1600-6143.2011.03633.x

55. Boer K, de Wit LE, Peters FS, Hesselink DA, Hofland LJ, Betjes MG, et al. Variations in DNA Methylation of Interferon Gamma and Programmed Death 1 in Allograft Rejection After Kidney Transplantation. Clin Epigenet (2016) 8:116. doi: 10.1186/s13148-016-0288-0

56. Zununi VS, Omidi Y, Ardalan M, Samadi N. Dysregulation of Urinary miR21 and miR-200b Associated With Interstitial Fibrosis and Tubular Atrophy (IFTA) in Renal Transplant Recipients. Clin Biochem (2017) 50:32-9. doi: 10.1016/j.clinbiochem.2016.08.007

57. Zununi VS, Poursadegh ZA, Mahmoodpoor F, Samadi N, Ardalan M, Omidi Y. Circulating miR-150, miR-192, miR-200b, and miR-423-3p as NonInvasive Biomarkers of Chronic Allograft Dysfunction. Arch Med Res (2017) 48:96-104. doi: 10.1016/j.arcmed.2017.03.004

58. Zununi VS, Poursadegh ZA, Ghanbarian H, Ghojazadeh M, Samadi N, Omidi Y, et al. Differential Expression of Circulating miR-21, miR-142-3p and miR-155 in Renal Transplant Recipients With Impaired Graft Function. Int Urol Nephrol (2017) 49:1681-9. doi: 10.1007/s11255-017-1602-2
59. Matz M, Heinrich F, Lorkowski C, Wu K, Klotsche J, Zhang Q, et al. MicroRNA Regulation in Blood Cells of Renal Transplanted Patients With Interstitial Fibrosis/Tubular Atrophy and Antibody-Mediated Rejection. PLoS One (2018) 13:e201925. doi: 10.1371/journal.pone.0201925

60. Nariman-Saleh-Fam Z, Bastami M, Ardalan M, Sharifi S, Hosseinian KS, Zununi VS. Cell-Free microRNA-148a Is Associated With Renal Allograft Dysfunction: Implication for Biomarker Discovery. J Cell Biochem (2019) 120:5737-46. doi: 10.1002/jcb.27860

61. Scian MJ, Maluf DG, David KG, Archer KJ, Suh JL, Wolen AR, et al. MicroRNA Profiles in Allograft Tissues and Paired Urines Associate With Chronic Allograft Dysfunction With IF/TA. Am J Transplant (2011) 11:2110-22. doi: 10.1111/j.1600-6143.2011.03666.x

62. Iwasaki K, Yamamoto T, Inanaga Y, Hiramitsu T, Miwa Y, Murotani K, et al. MiR-142-5p and miR-486-5p as Biomarkers for Early Detection of Chronic Antibody-Mediated Rejection in Kidney Transplantation. Biomarkers (2017) 22:45-54. doi: 10.1080/1354750X.2016.1204000

63. Sigdel TK, Gao Y, He J, Wang A, Nicora CD, Fillmore TL, et al. Mining the Human Urine Proteome for Monitoring Renal Transplant Injury. Kidney Int (2016) 89:1244-52. doi: 10.1016/j.kint.2015.12.049

64. Srivastava M, Torosyan Y, Eidelman O, Jozwik C, Pollard HB, Mannon R. Reduced PARP1 as a Serum Biomarker for Graft Rejection in Kidney Transplantation. J Proteomics Bioinform (2015) 8:31-8. doi: 10.4172/ jpb. 1000350

65. Srivastava M, Eidelman O, Torosyan Y, Jozwik C, Mannon RB, Pollard HB. Elevated Expression Levels of ANXA11, Integrins Beta3 and Alpha3, and TNF-alpha Contribute to a Candidate Proteomic Signature in Urine for Kidney Allograft Rejection. Proteomics Clin Appl (2011) 5:311-21. doi: 10.1002/prca.201000109

66. Rabant M, Amrouche L, Lebreton X, Aulagnon F, Benon A, Sauvaget V, et al. Urinary C-X-C Motif Chemokine 10 Independently Improves the Noninvasive Diagnosis of Antibody-Mediated Kidney Allograft Rejection. J Am Soc Nephrol (2015) 26:2840-51. doi: 10.1681/ASN.2014080797

67. Blydt-Hansen TD, Gibson IW, Gao A, Dufault B, Ho J. Elevated Urinary CXCL10-to-creatinine Ratio is Associated With Subclinical and Clinical Rejection in Pediatric Renal Transplantation. Transplantation (2015) 99:797-804. doi: 10.1097/TP.0000000000000419

68. Carreras-Planella L, Cucchiari D, Canas L, Juega J, Franquesa M, Bonet J, et al. Urinary Vitronectin Identifies Patients With High Levels of Fibrosis in Kidney Grafts. J Nephrol (2020). doi: 10.1007/s40620-020-00886-y

69. Lammerts R, Eisenga MF, Alyami M, Daha MR, Seelen MA, Pol RA, et al. Urinary Properdin and Sc5b-9 Are Independently Associated With Increased Risk for Graft Failure in Renal Transplant Recipients. Front Immunol (2019) 10:2511. doi: 10.3389/fimmu.2019.02511

70. Jung HY, Lee CH, Choi JY, Cho JH, Park SH, Kim YL, et al. Potential Urinary Extracellular Vesicle Protein Biomarkers of Chronic Active Antibody-Mediated Rejection in Kidney Transplant Recipients. J Chromatogr B Analyt Technol BioMed Life Sci (2020) 1138:121958. doi: 10.1016/j.jchromb.2019.121958

71. Cassidy H, Slyne J, O'Kelly P, Traynor C, Conlon PJ, Johnston O, et al. Urinary Biomarkers of Chronic Allograft Nephropathy. Proteomics Clin Appl (2015) 9:574-85. doi: 10.1002/prca.201400200

72. Sottong PR, Rosebrock JA, Britz JA, Kramer TR. Measurement of TLymphocyte Responses in Whole-Blood Cultures Using Newly Synthesized DNA and ATP. Clin Diagn Lab Immunol (2000) 7:307-11. doi: 10.1128/CDLI.7.2.307-311.2000

73. Kalantari S, Chashmniam S, Nafar M, Samavat S, Rezaie D, Dalili N. A Noninvasive Urine Metabolome Panel as Potential Biomarkers for Diagnosis of T Cell-Mediated Renal Transplant Rejection. Omics (2020) 24:140-7. doi: 10.1089/omi.2019.0158

74. Banas M, Neumann S, Eiglsperger J, Schiffer E, Putz FJ, Reichelt-Wurm S, et al. Identification of a Urine Metabolite Constellation Characteristic for Kidney Allograft Rejection. Metabolomics (2018) 14:116. doi: 10.1007/ s11306-018-1419-8

75. Zheng L, Wang J, Gao W, Hu C, Wang S, Rong R, et al. GC/MS-Based Urine Metabolomics Analysis of Renal Allograft Recipients With Acute Rejection. J Transl Med (2018) 16:202. doi: 10.1186/s12967-018-1584-6

76. Kim SY, Kim BK, Gwon MR, Seong SJ, Ohk B, Kang WY, et al. Urinary Metabolomic Profiling for Noninvasive Diagnosis of Acute T Cell-Mediated 
Rejection After Kidney Transplantation. J Chromatogr B Analyt Technol BioMed Life Sci (2019) 1118-1119:157-63. doi: 10.1016/j.jchromb.2019.04.047

77. Beier UH, Hartung EA, Concors S, Hernandez PT, Wang Z, Perry C, et al. Tissue Metabolic Profiling Shows That Saccharopine Accumulates During Renal Ischemic-Reperfusion Injury, While Kynurenine and Itaconate Accumulate in Renal Allograft Rejection. Metabolomics (2020) 16:65. doi: 10.1007/s11306-020-01682-2

78. Sigdel TK, Schroeder AW, Yang J, Sarwal RD, Liberto JM, Sarwal MM. Targeted Urine Metabolomics for Monitoring Renal Allograft Injury and Immunosuppression in Pediatric Patients. J Clin Med (2020) 9:2341. doi: $10.3390 /$ jcm 9082341

79. Jacquemont L, Tilly G, Yap M, Doan-Ngoc TM, Danger R, Guerif P, et al. Terminally Differentiated Effector Memory Cd8(+) T Cells Identify Kidney Transplant Recipients At High Risk of Graft Failure. J Am Soc Nephrol (2020) 31:876-91. doi: 10.1681/ASN.2019080847

80. Ashokkumar C, Talukdar A, Sun Q, Higgs BW, Janosky J, Wilson P, et al. Allospecific CD154+ T Cells Associate With Rejection Risk After Pediatric Liver Transplantation. Am J Transplant (2009) 9:179-91. doi: 10.1111/ j.1600-6143.2008.02459.x

81. Ashokkumar C, Shapiro R, Tan H, Ningappa M, Elinoff B, Fedorek S, et al. Allospecific CD154+ T-Cytotoxic Memory Cells Identify Recipients Experiencing Acute Cellular Rejection After Renal Transplantation. Transplantation (2011) 92:433-8. doi: 10.1097/TP.0b013e318225276d

82. Crespo E, Cravedi P, Martorell J, Luque S, Melilli E, Cruzado JM, et al. Posttransplant Peripheral Blood Donor-Specific Interferon-Gamma Enzyme-Linked Immune Spot Assay Differentiates Risk of Subclinical Rejection and De Novo Donor-Specific Alloantibodies in Kidney Transplant Recipients. Kidney Int (2017) 92:201-13. doi: 10.1016/j.kint. 2016.12.024

83. Yan L, Li Y, Li Y, Wu X, Wang X, Wang L, et al. Increased Circulating Tfh to Tfr Ratio in Chronic Renal Allograft Dysfunction: A Pilot Study. BMC Immunol (2019) 20:26. doi: 10.1186/s12865-019-0308-x

84. Liu Y, Hu J, Liu D, Zhou S, Liao J, Liao G, et al. Single-Cell Analysis Reveals Immune Landscape in Kidneys of Patients With Chronic Transplant Rejection. Theranostics (2020) 10:8851-62. doi: 10.7150/thno.48201

85. Khatri P, Roedder S, Kimura N, De Vusser K, Morgan AA, Gong Y, et al. A Common Rejection Module (CRM) for Acute Rejection Across Multiple Organs Identifies Novel Therapeutics for Organ Transplantation. J Exp Med (2013) 210:2205-21. doi: 10.1084/jem.20122709

86. Garcia-Gimenez JL, Seco-Cervera M, Tollefsbol TO, Roma-Mateo C, PeiroChova L, Lapunzina P, et al. Epigenetic Biomarkers: Current Strategies and Future Challenges for Their Use in the Clinical Laboratory. Crit Rev Clin Lab Sci (2017) 54:529-50. doi: 10.1080/10408363.2017.1410520

87. Liu H, Li P, Wei Z, Zhang C, Xia M, Du Q, et al. Regulation of T Cell Differentiation and Function by Epigenetic Modification Enzymes. Semin Immunopathol (2019) 41:315-26. doi: 10.1007/s00281-019-00731-w

88. Mas VR, Le TH, Maluf DG. Epigenetics in Kidney Transplantation: Current Evidence, Predictions, and Future Research Directions. Transplantation (2016) 100:23-38. doi: 10.1097/TP.0000000000000878

89. Wing MR, Devaney JM, Joffe MM, Xie D, Feldman HI, Dominic EA, et al. DNA Methylation Profile Associated With Rapid Decline in Kidney Function: Findings From the CRIC Study. Nephrol Dial Transplant (2014) 29:864-72. doi: 10.1093/ndt/gft537

90. Rodriguez RM, Lopez-Larrea C, Suarez-Alvarez B. Epigenetic Dynamics During CD4(+) T Cells Lineage Commitment. Int J Biochem Cell Biol (2015) 67:75-85. doi: 10.1016/j.biocel.2015.04.020

91. Jones B, Chen J. Inhibition of IFN-gamma Transcription by Site-Specific Methylation During T Helper Cell Development. EMBO J (2006) 25:244352. doi: $10.1038 /$ s.emboj.7601148

92. Bechtel W, McGoohan S, Zeisberg EM, Muller GA, Kalbacher H, Salant DJ, et al. Methylation Determines Fibroblast Activation and Fibrogenesis in the Kidney. Nat Med (2010) 16:544-50. doi: 10.1038/nm.2135

93. Bontha SV, Maluf DG, Archer KJ, Dumur CI, Dozmorov MG, King AL, et al. Effects of DNA Methylation on Progression to Interstitial Fibrosis and Tubular Atrophy in Renal Allograft Biopsies: A Multi-Omics Approach. Am J Transplant (2017) 17:3060-75. doi: 10.1111/ajt.14372

94. Sigdel TK, Kaushal A, Gritsenko M, Norbeck AD, Qian WJ, Xiao W, et al. Shotgun Proteomics Identifies Proteins Specific for Acute Renal Transplant
Rejection. Proteomics Clin Appl (2010) 4:32-47. doi: 10.1002/prca. 200900124

95. Metzger J, Chatzikyrkou C, Broecker V, Schiffer E, Jaensch L, Iphoefer A, et al. Diagnosis of Subclinical and Clinical Acute T-cell-mediated Rejection in Renal Transplant Patients by Urinary Proteome Analysis. Proteomics Clin Appl (2011) 5:322-33. doi: 10.1002/prca.201000153

96. Kuo HH, Fan R, Dvorina N, Chiesa-Vottero A, Baldwin WR. Platelets in Early Antibody-Mediated Rejection of Renal Transplants. J Am Soc Nephrol (2015) 26:855-63. doi: 10.1681/ASN.2013121289

97. Morrell CN, Sun H, Swaim AM, Baldwin WR. Platelets an Inflammatory Force in Transplantation. Am J Transplant (2007) 7:2447-54. doi: 10.1111/ j.1600-6143.2007.01958.x

98. Scheuerer B, Ernst M, Durrbaum-Landmann I, Fleischer J, Grage-Griebenow E, Brandt E, et al. The CXC-chemokine Platelet Factor 4 Promotes Monocyte Survival and Induces Monocyte Differentiation Into Macrophages. Blood (2000) 95:1158-66. doi: 10.1182/blood.V95.4.1158.004k31_1158_1166

99. Tinckam KJ, Djurdjev O, Magil AB. Glomerular Monocytes Predict Worse Outcomes After Acute Renal Allograft Rejection Independent of C4d Status. Kidney Int (2005) 68:1866-74. doi: 10.1111/j.1523-1755.2005.00606.x

100. Wishart DS. Metabolomics: A Complementary Tool in Renal Transplantation. Contrib Nephrol (2008) 160:76-87. doi: 10.1159/ 000125935

101. Naesens M, Sarwal MM. Molecular Diagnostics in Transplantation. Nat Rev Nephrol (2010) 6:614-28. doi: 10.1038/nrneph.2010.113

102. Nasr M, Sigdel T, Sarwal M. Advances in Diagnostics for Transplant Rejection. Expert Rev Mol Diagn (2016) 16:1121-32. doi: 10.1080/ 14737159.2016.1239530

103. Blydt-Hansen TD, Sharma A, Gibson IW, Wishart DS, Mandal R, Ho J, et al. Urinary Metabolomics for Noninvasive Detection of Antibody-Mediated Rejection in Children After Kidney Transplantation. Transplantation (2017) 101:2553-61. doi: 10.1097/TP.0000000000001662

104. Mincham CM, Gibson IW, Sharma A, Wiebe C, Mandal R, Rush D, et al. Evolution of Renal Function and Urinary Biomarker Indicators of Inflammation on Serial Kidney Biopsies in Pediatric Kidney Transplant Recipients With and Without Rejection. Pediatr Transplant (2018) 22: e13202. doi: 10.1111/petr.13202

105. Ravaioli M, Neri F, Lazzarotto T, Bertuzzo VR, Di Gioia P, Stacchini G, et al. Immunosuppression Modifications Based on an Immune Response Assay: Results of a Randomized, Controlled Trial. Transplantation (2015) 99:162532. doi: 10.1097/TP.0000000000000650

106. Bestard O, Nickel P, Cruzado JM, Schoenemann C, Boenisch O, Sefrin A, et al. Circulating Alloreactive T Cells Correlate With Graft Function in Longstanding Renal Transplant Recipients. J Am Soc Nephrol (2008) 19:1419-29. doi: 10.1681/ASN.2007050539

107. Koyama I, Nadazdin O, Boskovic S, Ochiai T, Smith RN, Sykes M, et al. Depletion of CD8 Memory T Cells for Induction of Tolerance of a Previously Transplanted Kidney Allograft. Am J Transplant (2007) 7:1055-61. doi: 10.1111/j.1600-6143.2006.01703.x

108. Rohan VS, Soliman KM, Alqassieh A, Alkhader D, Patel N, Nadig SN. Renal Allograft Surveillance With Allospecific T-cytotoxic Memory Cells. Ren Fail (2020) 42:1152-6. doi: 10.1080/0886022X.2020.1846054

109. Chazaud B. Macrophages: Supportive Cells for Tissue Repair and Regeneration. Immunobiology (2014) 219:172-8. doi: 10.1016/ j.imbio.2013.09.001

110. Pilmore HL, Painter DM, Bishop GA, McCaughan GW, Eris JM. Early UpRegulation of Macrophages and Myofibroblasts: A New Marker for Development of Chronic Renal Allograft Rejection. Transplantation (2000) 69:2658-62. doi: 10.1097/00007890-200006270-00028

111. Ziai F, Nagano H, Kusaka M, Coito AJ, Troy JL, Nadeau KC, et al. Renal Allograft Protection With Losartan in Fisher->Lewis Rats: Hemodynamics, Macrophages, and Cytokines. Kidney Int (2000) 57:2618-25. doi: 10.1046/ j.1523-1755.2000.00122.x

112. Hwang B, Lee JH, Bang D. Single-Cell RNA Sequencing Technologies and Bioinformatics Pipelines. Exp Mol Med (2018) 50:1-14. doi: 10.1038/s12276018-0071-8

113. Haque A, Engel J, Teichmann SA, Lonnberg T. A Practical Guide to SingleCell RNA-sequencing for Biomedical Research and Clinical Applications. Genome Med (2017) 9:75. doi: 10.1186/s13073-017-0467-4 
114. Mao S, Wang C, Dong G. Evaluation of Inter-Laboratory and Cross-Platform Concordance of DNA Microarrays Through Discriminating Genes and Classifier Transferability. J Bioinform Comput Biol (2009) 7:157-73. doi: $10.1142 / \mathrm{S} 0219720009004011$

115. Salcido-Ochoa F, Allen JJ. Biomarkers and a Tailored Approach for Immune Monitoring in Kidney Transplantation. World J Transplant (2017) 7:276-84. doi: 10.5500 /wjt.v7.i6.276

116. Madill-Thomsen K, Perkowska-Ptasinska A, Bohmig GA, Eskandary F, Einecke G, Gupta G, et al. Discrepancy Analysis Comparing Molecular and Histology Diagnoses in Kidney Transplant Biopsies. Am J Transplant (2020) 20:1341-50. doi: 10.1111/ajt.15752

117. Loupy A, Lefaucheur C. Antibody-Mediated Rejection of Solid-Organ Allografts. N Engl J Med (2018) 379:1150-60. doi: 10.1056/NEJMra1802677

118. Haas M, Mirocha J, Reinsmoen NL, Vo AA, Choi J, Kahwaji JM, et al. Differences in Pathologic Features and Graft Outcomes in AntibodyMediated Rejection of Renal Allografts Due to Persistent/Recurrent Versus De Novo Donor-Specific Antibodies. Kidney Int (2017) 91:729-37. doi: 10.1016/j.kint.2016.10.040

119. Noguchi H, Nakagawa K, Ueki K, Tsuchimoto A, Kaku K, Okabe Y, et al. Response to Treatment for Chronic-Active T Cell-Mediated Rejection in Kidney Transplantation: A Report of 3 Cases. Transplant Direct (2020) 6: e628. doi: 10.1097/TXD.0000000000001079

120. Trivedi HL, Terasaki PI, Feroz A, Everly MJ, Vanikar AV, Shankar V, et al. Abrogation of Anti-HLA Antibodies Via Proteasome Inhibition. Transplantation (2009) 87:1555-61. doi: 10.1097/TP.0b013e3181a4b91b

121. Waiser J, Budde K, Schutz M, Liefeldt L, Rudolph B, Schonemann C, et al. Comparison Between Bortezomib and Rituximab in the Treatment of Antibody-Mediated Renal Allograft Rejection. Nephrol Dial Transplant (2012) 27:1246-51. doi: 10.1093/ndt/gfr465

122. Eskandary F, Regele H, Baumann L, Bond G, Kozakowski N, Wahrmann M, et al. A Randomized Trial of Bortezomib in Late Antibody-Mediated Kidney Transplant Rejection. J Am Soc Nephrol (2018) 29:591-605. doi: 10.1681/ ASN.2017070818

123. Cornell LD, Schinstock CA, Gandhi MJ, Kremers WK, Stegall MD. Positive Crossmatch Kidney Transplant Recipients Treated With Eculizumab: Outcomes Beyond 1 Year. Am J Transplant (2015) 15:1293-302. doi: 10.1111/ajt.13168

124. Kulkarni S, Kirkiles-Smith NC, Deng YH, Formica RN, Moeckel G, Broecker V, et al. Eculizumab Therapy for Chronic Antibody-Mediated Injury in Kidney Transplant Recipients: A Pilot Randomized Controlled Trial. Am J Transplant (2017) 17:682-91. doi: 10.1111/ajt.14001

125. Montgomery RA, Loupy A, Segev DL. Antibody-Mediated Rejection: New Approaches in Prevention and Management. Am J Transplant (2018) 18:317. doi: $10.1111 /$ ajt.14584

126. Choi J, Aubert O, Vo A, Loupy A, Haas M, Puliyanda D, et al. Assessment of Tocilizumab (Anti-Interleukin-6 Receptor Monoclonal) as a Potential Treatment for Chronic Antibody-Mediated Rejection and Transplant Glomerulopathy in HLA-Sensitized Renal Allograft Recipients. Am J Transplant (2017) 17:2381-9. doi: 10.1111/ajt.14228

127. Montgomery RA, Orandi BJ, Racusen L, Jackson AM, Garonzik-Wang JM, Shah T, et al. Plasma-Derived C1 Esterase Inhibitor for Acute AntibodyMediated Rejection Following Kidney Transplantation: Results of a Randomized Double-Blind Placebo-Controlled Pilot Study. Am J Transplant (2016) 16:3468-78. doi: 10.1111/ajt.13871

128. Viglietti D, Gosset C, Loupy A, Deville L, Verine J, Zeevi A, et al. C1 Inhibitor in Acute Antibody-Mediated Rejection Nonresponsive to Conventional Therapy in Kidney Transplant Recipients: A Pilot Study. Am J Transplant (2016) 16:1596-603. doi: 10.1111/ajt.13663

129. Banham GD, Flint SM, Torpey N, Lyons PA, Shanahan DN, Gibson A, et al. Belimumab in Kidney Transplantation: An Experimental Medicine, Randomised, Placebo-Controlled Phase 2 Trial. Lancet (2018) 391:261930. doi: 10.1016/S0140-6736(18)30984-X
130. Jordan SC, Choi J, Kim I, Wu G, Toyoda M, Shin B, et al. Interleukin-6, A Cytokine Critical to Mediation of Inflammation, Autoimmunity and Allograft Rejection: Therapeutic Implications of IL-6 Receptor Blockade. Transplantation (2017) 101:32-44. doi: 10.1097/TP.0000000000001452

131. Aletaha D, Smolen JS. Diagnosis and Management of Rheumatoid Arthritis: A Review. JAMA (2018) 320:1360-72. doi: 10.1001/jama.2018.13103

132. Vo AA, Choi J, Kim I, Louie S, Cisneros K, Kahwaji J, et al. A Phase I/Ii Trial of the Interleukin-6 Receptor-Specific Humanized Monoclonal (Tocilizumab) + Intravenous Immunoglobulin in Difficult to Desensitize Patients. Transplantation (2015) 99:2356-63. doi: 10.1097/TP.0000000000000741

133. Eskandary F, Durr M, Budde K, Doberer K, Reindl-Schwaighofer R, Waiser J, et al. Clazakizumab in Late Antibody-Mediated Rejection: Study Protocol of a Randomized Controlled Pilot Trial. Trials (2019) 20:37. doi: 10.1186/ s13063-018-3158-6

134. NIH U.S. National Library of Medicine. A Pilot Trial of Clazakizumab in Late Abmr. Available at: https://clinicaltrials.gov/ct2/show/NCT03444103.

135. NIH U.S. National Library of Medicine. Interleukin 6 Blockade Modifying Antibody-Mediated Graft Injury and Estimated Glomerular Filtration Rate (Egfr) Decline (Imagine). Available at: https://ClinicalTrials.gov/show/ NCT03744910.

136. Berger M, Baldwin WR, Jordan SC. Potential Roles for C1 Inhibitor in Transplantation. Transplantation (2016) 100:1415-24. doi: 10.1097/ TP.0000000000000995

137. Davis AR, Lu F, Mejia P. C1 Inhibitor, a Multi-Functional Serine Protease Inhibitor. Thromb Haemost (2010) 104:886-93. doi: 10.1160/TH10-01-0073

138. NIH U.S. National Library of Medicine. A Multicenter Study to Evaluate the Efficacy and Safety of Cinryze ${ }^{\circledR}$ for the Treatment of Acute Antibody-Mediated Rejection in Participants With Kidney Transplant. Available at: https:// clinicaltrials.gov/ct2/show/NCT02547220.

139. NIH U.S. National Library of Medicine. Efficacy and Safety of Human Plasma-Derived C1-esterase Inhibitor as Add-on to Standard of Care for the Treatment of Refractory Antibody Mediated Rejection (AMR) in Adult Renal Transplant Recipients. Available at: https://ClinicalTrials.gov/show/ NCT03221842.

140. Clatworthy MR. B-Cell Regulation and its Application to Transplantation. Transpl Int (2014) 27:117-28. doi: 10.1111/tri.12160

141. Navarra SV, Guzman RM, Gallacher AE, Hall S, Levy RA, Jimenez RE, et al. Efficacy and Safety of Belimumab in Patients With Active Systemic Lupus Erythematosus: A Randomised, Placebo-Controlled, Phase 3 Trial. Lancet (2011) 377:721-31. doi: 10.1016/S0140-6736(10)61354-2

142. Bath NM, Ding X, Verhoven BM, Wilson NA, Coons L, Sukhwal A, et al. Autoantibody Production Significantly Decreased With APRIL/BLyS Blockade in Murine Chronic Rejection Kidney Transplant Model. PLoS One (2019) 14:e223889. doi: 10.1371/journal.pone.0223889

143. Bloom RD, Bromberg JS, Poggio ED, Bunnapradist S, Langone AJ, Sood P, et al. Cell-Free DNA and Active Rejection in Kidney Allografts. J Am Soc Nephrol (2017) 28:2221-32. doi: 10.1681/ASN.2016091034

144. NIH U.S. National Library of Medicine. Clazakizumab for Chronic and Active Antibody Mediated Rejection Post-Kidney Transplant. Available at: https://clinicaltrials.gov/ct2/show/NCT03380377.

Conflict of Interest: The authors declare that the research was conducted in the absence of any commercial or financial relationships that could be construed as a potential conflict of interest.

Copyright $\odot 2021$ Lai, Zheng, Mathew, Gallon, Leventhal and Zhang. This is an openaccess article distributed under the terms of the Creative Commons Attribution License (CC BY). The use, distribution or reproduction in other forums is permitted, provided the original author(s) and the copyright owner(s) are credited and that the original publication in this journal is cited, in accordance with accepted academic practice. No use, distribution or reproduction is permitted which does not comply with these terms. 